\title{
A POLISH ADAPTATION OF LEADERSHIP SCALE FOR SPORTS - A QUESTIONNAIRE EXAMINING COACHING BEHAVIOR
}

doi: 10.2478/humo-2013-0032

\section{ZUZANNA WAŁACH-BIŚTA}

University of Silesia, Katowice, Poland

\begin{abstract}
Purpose. The main purpose of this study was the development of a Polish version of the scale developed by P. Chelladurai and S. Saleh for examining coaching behavior (the Leadership Scale for Sports; LSS). Methods. The Polish version was constructed in two stages. In the first stage, the psychometric equivalence of the Polish translation was estimated by providing a Polish/English version of the questionnaire to a bilingual sample. Following verification of the psychometric properties of the experimental version and the adding of additional items to the scale, a second stage of analysis was performed using additional samples to assess the reliability and validity of the new scale. In total, 560 university physical education students, 180 athletes, and 75 coaches were recruited to participate in the study. The final version was deemed a reliable and valid reproduction of the LSS, consisting of 40 items representing five dimensions measuring coaching behavior. Results. Measures of reliability (internal consistency using Cronbach's alpha and test-retest reliability) as well as validity (exploratory factory analysis with principal component analysis) of the final version of the Polish adaptation of the Leadership Scale for Sports were found to be satisfactory. It was determined that the Polish adaptation of the LSS is characterized by good psychometric properties and can be widely used in the sports environment. Conclusions. The Polish adaptation of the LSS reflects the five-factor structure of the original scale, closely reproducing the dimensions of training and instruction, democratic behavior, autocratic behavior, social support, and positive feedback. It can be used both for the measurement athletes' preferences for coaching behavior and for assessing coaching behavior as observed by athletes.
\end{abstract}

Key words: psychology, sports, questionnaire, leadership, coaching

\section{Introduction}

Coaches have to act as leaders in their professional career and should therefore possess a number of leadership qualities, such as knowing how to adapt their behavior and actions to meet the requirements and expectations of the team they are coaching [1]. In effect, a coach is a type of specialist who attempts to develop the maximum athletic potential of his/her athletes by developing and enacting a training process [2, 3]. Coaches are not only responsible for continually improving their athletes' physical fitness, movement coordination, technical-tactical skills, and theoretical and methodological understanding of the sport but also play a large role in developing motivation and educating their players [1]. Coaches also spend an incredible amount of time with their players, often developing emotional and close relationships [2]. This is naturally advantageous, as coaches should be familiar with and understand their players' expectations and personal preferences. Unfortunately, in practice, many coaches lament they are unable to communicate with their players. These differences commonly arise from differences between the types of coaching styles an athlete prefers and the coach's actual behavior and attitude, all of which have a significant impact not just on player satisfaction but also sporting success $[4,5]$.

In 1978, Chelladurai introduced the Multidimensional Model of Leadership in Sport, a synthesis of earlier theories on the issue of leadership [6]. Subsequent research in the field of sports psychology found this model to be the most successful tool that not only successfully takes a holistic approach to the issue of coaching/leadership but is also suitable in the sporting environment $[5,7,8]$. Chelladurai's model emphasized that the effectiveness of coaching behavior is dependent on the interplay between players' preferences for specific types of coaching behavior and the numerous contextual conditions and requirements that arise. Two years later, Chelladurai with Saleh developed a questionnaire named the Leadership Scale for Sports as an instrument to test the adequacy of the original model [9] as well as being dissatisfied with the absence of any analogue tools that could be used to measure coaching behavior while also integrating the specificity of a given sport and being able to adapt to it [10]. Despite its success in studies on sports leadership around the world and in the United States, this valuable tool has not yet been adapted in Poland [11-19]. This is despite the fact that a revised version of this questionnaire, the Revised Leadership Scale for Sports [20], was translated into Polish. However, the final result did not meet the requirements of reliability and validity and therefore was a tool that could not be widely used [21]. In response to the growing demand for this type of tool in Poland, it was decided to translate and develop a Polish adaptation of the original version of the Leadership Scale for Sports. The present article seeks to describe the process of developing this adaptation of this scale as well as the results of psychometric analysis to confirm its reliability and validity. 


\section{Leadership Scale for Sports - original version}

As mentioned previously, the Leadership Scale for Sports (LSS) was based on Chelladurai and Saleh's Multidimensional Model of Leadership in Sport [10]. This scale analyzes five salient dimensions of coaching behavior (Tab. 1). It is used to determine to what extent a coach provides positive feedback, social support, training and instruction to his/her athletes as well as the coach's propensity for autocratic/democratic behavior. It consists of one factor that is directly related to group tasks (training and instruction), two decision-making style factors (democratic and autocratic behavior), and two motivational factors (positive feedback and social support) [10]. The original questionnaire is made up of 40 items. A respondent rates their level of agreement using a five-point scale: always, often (about $75 \%$ of the time), occasionally (about $50 \%$ of the time), seldom (about $25 \%$ of the time), and never.

The original LSS scale consists of three versions that are used to measure [10]:

1) athletes' preference for coaching behavior,

2) athletes' perception of their coach's behavior, and

3) coaches' perception of their own behavior.

All three versions of the LSS are identical in terms of structure and the wording of each item. The only difference arises from the instructions that are provided to the respondent. In the "Athletes' Preference" version, an athlete is asked to express how they would like a coach to behave towards them. In the "Athletes' Perception" version, the athlete rates how their coach actually behaves. The third version, “Coaches' Perception", is used to study coaches by having them subjectively self-report how often they behave in certain ways relative to their players.

The first two versions of the LSS questionnaire were put through comprehensive psychometric analysis. When developing the Leadership Scale for Sports, its authors tested a large sample of physical education university students and professional athletes, who completed the versions for what type of behavior they preferred from their coach and how they actually perceived their coach's behavior [10]. For analysis of the scale's reliability, Chelladurai and Saleh studied internal consistency with Cronbach's alpha and estimated test-retest reliability. Internal consistency estimates for each of the factor subscales (dimensions), depending on which version was used, ranged from 0.45 (for autocratic behavior in athletes' preferences for coaching behavior) to 0.93 (training and instruction in athletes' perception of coaching behavior); more detailed data of their results are provided in Table 2.

The original authors of the scale analyzed test-retest reliability by administering the questionnaire again, fourweeks after it was first administered, on the same sample of physical education students. Correlation analysis be-

Table 1. Behavioral dimensions of leadership in sports (based on Chelladurai [9])

Dimension Description

\begin{tabular}{|c|c|c|c|}
\hline Training and instruction & \multicolumn{3}{|c|}{$\begin{array}{l}\text { Coaching behavior aimed at improving the athletes' performance by emphasizing and facilitating } \\
\text { hard and strenuous training. Here, the coach's behavior helps athletes reach their maximum } \\
\text { physical potential. Instructing athletes is a necessary quality of coaches, and includes instruction } \\
\text { in the skills, techniques, and tactics of their sport. It also includes clarifying the relationships } \\
\text { among teammates as well as organizing and coordinating athletes' activities. }\end{array}$} \\
\hline Democratic behavior & \multicolumn{3}{|c|}{$\begin{array}{l}\text { Coaching behavior that allows greater athlete participation in decisions pertaining to group } \\
\text { goals, practice methods, and game tactics and strategies. }\end{array}$} \\
\hline Autocratic behavior & \multicolumn{3}{|c|}{$\begin{array}{l}\text { Coaching behavior that involves independence in decision making and stresses personal } \\
\text { authority over his/her athletes; this is a dominating form of behavior. }\end{array}$} \\
\hline Social support & \multicolumn{3}{|c|}{$\begin{array}{l}\text { Coaching behavior characterized by a concern for the welfare of individual athletes, } \\
\text { which includes positive group atmosphere and warm interpersonal relations with members. }\end{array}$} \\
\hline Positive feedback & \multicolumn{3}{|c|}{$\begin{array}{l}\text { Coaching behavior that reinforces an athlete by recognizing and rewarding good performance } \\
\text { as well as providing appropriate feedback as to how well an athlete trains or performs. }\end{array}$} \\
\hline \multirow{2}{*}{ Coaching dimension } & \multirow{2}{*}{$\begin{array}{l}\text { Physical education students }(n=102) \\
\text { Athletes' preference }\end{array}$} & \multicolumn{2}{|c|}{ Athletes $(n=223)$} \\
\hline & & Athletes' preference & Athletes' perception \\
\hline Training and instruction & 0.76 & 0.83 & 0.93 \\
\hline Democratic behavior & 0.77 & 0.75 & 0.87 \\
\hline Autocratic behavior & 0.66 & 0.45 & 0.79 \\
\hline Social support & 0.72 & 0.70 & 0.86 \\
\hline Positive feedback & 0.79 & 0.82 & 0.92 \\
\hline
\end{tabular}


tween the first and second test found that test-retest reliability was high and ranged from 0.71 (for social support) to 0.82 (democratic behavior).

The theoretical accuracy of the scale was determined by using exploratory factor analysis with orthogonal varimax rotation, where the most optimal number of items was determined using Kaiser Normalization and Cattell's Scree test [10]. A few years later, Chelladurai and Riemer [22] returned to the original version of the LSS to apply confirmatory factor analysis in order to redefine the scale's validity. The obtained results $\left[x^{2} / d f<2\right.$; root mean square error of approximation $($ RMSEA $)=0.06$ and 0.062] indicated the good fit of the developed model.

\section{Material and methods}

The first stage of research on the Leadership Scale for Sports - experimental version

Work on a Polish adaptation of the Leadership Scale for Sports began by first preparing a suitable Polish translation of the original scale (written in English). The original authors were contacted in order to obtain their permission for reproducing the scale. Three professionally translated versions of the scale were examined by a specially formed group of researchers; on the basis of their decision one of the versions that best reflected all of the 40 items from the original questionnaire was selected.

The equivalence of the translated version to the original was estimated by determining the strength of correlation by having bilingual subjects complete a version with bilingual responses $(n=10)$ so as to check if the Polish adaptation's consistency with the original [23]. The results (Spearman's $r_{s}=0.91$ for the entire scale; ranging from 0.69 for social support to 0.91 for positive feedback) indicated a high semantic similarity with the original.

Following this a priori analysis, the Polish adaptation of the Leadership Scale for Sports was administered to three research groups:

1) first and second year physical education students $(n=170)$ attending the University of Physical Education in Katowice, Poland, all of whom had been training in a sport for more than one year, who completed the Polish adaptation of the LSS questionnaire used for measuring preferred coaching behavior,

2) professional athletes of local sports clubs $(n=90)$, who completed the Polish LSS version used for measuring perceived coaching behavior, and

3) sports coaches $(n=75)$, who completed the Polish LSS used for measuring coaches' perception of their own behavior.

In order to determine the internal consistency of the Polish adaptation of the LSS, exploratory factor analysis using principal component analysis was used. Bartlett's test of sphericity confirmed the validity of fac- tor analysis. The Kaiser-Meyer-Olkin (KMO) measure of sampling adequacy in the first two cases was adequate ( 0.75 for students, 0.73 for athletes). However, this measure for the group of coaches was only 0.56 , therefore this group was excluded from further analysis. The Scree test and Kaiser Normalization were then applied in order to determine the number of factors that comprised the Polish LSS. It was assumed that the Polish adaptation would also present a five-factor solution as in the original version. Analysis of the Scree test confirmed the validity of this assumption (Fig. 1), with the five-factor model explaining for $42.3 \%$ (preference for coaching behavior by the students) and $51.3 \%$ (perception of coaching behavior by the athletes) of total variance. The obtained results were consistent with those obtained by Chelladurai and Saleh in the original version of the LSS [10].

Following the above analysis, the most meaningful items were selected from the two obtained solutions to build each factor. Items were selected by applying the following criteria: 1) the item should have a high loading on the same factor in both versions and 2) the items should have a loading of 0.30 or more in both versions. This method extracted 22 items in total: 8 items for training and instruction, 5 items for democratic behavior, 3 items for social support, 5 items for positive feedback, and 1 item for autocratic behavior. Confirmatory factor analysis confirmed the factorial validity of the 22 extracted items among the five factors. The obtained results indicated that the model was an acceptable fit to the data $\left[x^{2}=357.43\right.$; $d f=200$; RMSEA = 0.05; GFI (Goodness of Fit $)=0.89$; AGFI (Adjusted Goodness of Fit Index) = 0.86)].

Analysis on the reliability of this experimental version of the LSS was based on internal consistency estimates using Cronbach's alpha for each of the extracted factors (excluding autocratic behavior due to too few items loading on the factor). The results ranged from $\alpha=0.60$ (for social support in the scale completed by the athletes) to $\alpha=0.84$ (for training and instruction in the scale completed by the athletes).

As a result of the low internal consistency of this experimental version of the Leadership Scale for Sports in Polish, it was decided to continue with a second stage of research aimed at better refining this research tool by improving its psychometric properties.

\section{The second stage of research on the Leadership} Scale for Sports - second version

The second stage of research involved adding additional items to the Polish adaptation of the Leadership Scale for Sports so as to better reflect the five leadership dimensions developed by Chelladurai and Saleh [10]. Athletes and coaches were recruited to aid in the process of creating new items. Some of the new items were modeled on the original items from the original Leadership Scale for Sports but adapted (rewritten) to better reflect the construct and reality of Polish life as based on the opinions of previous respondents and the recruited group 
of athletes and coaches. For example, the item "Invites athletes to his/her home", which was rejected in the first stage of the study during statistical analysis, was rewritten as "Initiates informal meetings with the athletes". The result of this phase of research was the creation of 28 new items, resulting in 50 items in a final Polish adaptation of the LSS.

In order to investigate the content validity of this adaptation of the questionnaire, a number of experts $(n=10)$ were asked to identify the representativeness of each item in regards to the subscales of each dimension. Kendall's coefficient of concordance $(W)$ was applied to assess the conformity of the experts' evaluation, finding a $W$ value of 0.44. Lawshe's content validity ratio (CVR) was then calculated for each item on the questionnaire. Based on the obtained results, all of the items for each of the subscales were considered by the experts to be reliable $(\mathrm{CVR}=0.8$ or CVR $=1)$ and therefore left without further modification. The final version of the LSS questionnaire was then administered to two groups:

1) first and second year physical education students ( $n=390,266$ males and 124 females) attending the University of Physical Education in Krakow, Poland, who completed the final version of the LSS used for measuring preferred coaching behavior, and

2) professional athletes $(n=90,52$ males and $38 \mathrm{fe-}$ males), competing in such sports as soccer, futsal, basketball, handball, volleyball, and artistic gymnastics, who completed the final version of the LSS for measuring perceived coaching behavior.

The psychometric results of the questionnaire were first analyzed by quantifying the discriminatory power of the individual items. The decision to include all 50 items in further psychometric analysis was based on several reasons: 1 ) the discriminative validity of almost all of the 50 items was more than $r_{b i}=0.31 ; 2$ ) the items in one version (preferred coaching behavior or perceived coaching bahavior) of the LSS reached values no higher than 0.3 , whereas in the other version (preferred coaching behavior or perceived coaching bahavior) they had much higher values (above 0.4); 3) all of the items in the questionnaire were found with high coefficients of concordance, which suggested that even in spite of having slightly lower discriminative power, the items should be included in the scale due to their high accuracy.

The next step was to perform exploratory factory analysis with principal component analysis. However, before this was performed, the validity of the scale was statistically analyzed similar to that in the first adaptation. Bartlett's test of sphericity as well as the KMO measure of sampling adequacy were adequate in both cases $(p<0.00 ; \mathrm{KMO}=0.61$ for the athletes; $p<0.00$; $\mathrm{KMO}=0.87$ for the students).

The five-factor structure of the scale therefore seemed to be the most justifiable solution (based on the Scree test, see Figure 1). This model explained for $42.11 \%$ (perception of coaching behavior by the athletes) and $40.50 \%$ (preference for coaching behavior by the students) of total variance.

The extracted 50 items were then subjected to varimax rotation. The selection criteria of the items for each subscale were similar to that in the first stage. The items included in each subscale needed to have the highest loading on its respective factor in both versions, i.e., for measuring athletes' preferences for specific coaching behavior as well as in the version measuring athletes' perception of their coaches' behavior. Additionally, the loading of one item on a factor should be above 0.25 in both versions. This analysis resulted in 40 items being extracted. The detailed factor loadings of each item in constructing the final adaptation of the Polish Leadership Scale for Sports are presented in Table 3.

Systematic analysis of the items' loading, performed in accordance with Helmes' criteria [24], demonstrated that this adaptation of the Leadership Scale for Sports was characterized by very high convergent validity and very good discriminant validity (for all five dimensional subscales the convergent validity was " 1 " whereas the coefficient of discriminant validity was "0" for both versions of the Polish LSS).

Confirmatory factor analysis included the techniques of generalized least squares and maximum likelihood. An absolute fit index of $x^{2} / d f=1857.59 / 730$ as well as a RMSEA of 0.06 confirmed the validity of the extracted five factors. The obtained results indicated the good fit of the five-factor model [25].

Analysis on the reliability of the Polish adaptation of the LSS was performed by measuring internal consistency using Cronbach's alpha and test-retest reliability for each of the extracted subscales, with these indicators of reliability presented in Table 4 . Four of the five subscales of the LSS investigating the preferences of athletes and three of the subscales measuring athletes' perceptions of their coaches' behavior had a Cronbach's alpha of 0.70 or higher, indicating an acceptable level of reliability. However, two subscales, autocratic behavior and social support, did not attain such high values. Nevertheless, they attained a Cronbach's alpha exceeding 0.60, which by some researchers is considered to be the lower acceptable limit of reliability in scales constructed with such a small number of items [26]. However, future researchers using this adaptation of the Leadership Scale for Sports should be aware of the lower internal consistency of the autocratic behavior and social support subscales and be cautious when interpreting their results.

Test-retest variability of this final version of the Polish LSS was measured four weeks after first administering the questionnaire (the version measuring athletes' preferences for coaching behavior) to the group of 60 physical education university students. Correlation analysis between first and second test results found that testretest reliability was high, from 0.70 for positive feedback, 0.73 for social support, 0.79 for training and instruction, 0.80 for autocratic behavior, and 0.82 for democratic behavior. 
Table 3. Factor loading of the extracted items

\begin{tabular}{|c|c|c|}
\hline Item & $\begin{array}{l}\text { Physical education } \\
\text { students }(n=390)\end{array}$ & $\begin{array}{c}\text { Athletes } \\
(n=90)\end{array}$ \\
\hline \multicolumn{3}{|l|}{ Training and instruction } \\
\hline Percentage of variance explained & 19.6 & 7.5 \\
\hline Explains to each athlete the technique and tactics of the sport* & 0.36 & 0.46 \\
\hline Figures ahead on what should be done* & 0.52 & 0.42 \\
\hline Expects every athlete to perform his/her assignment to the last detail* & 0.56 & 0.62 \\
\hline Understands that the performance of the athlete depends on many elements* & 0.43 & 0.57 \\
\hline Explains to every athlete what he/she should or should not do & 0.63 & 0.47 \\
\hline Specifies in detail what is expected of the athlete* & 0.63 & 0.38 \\
\hline Instructs every athlete individually on what skills are necessary in the sport* & 0.58 & 0.53 \\
\hline Explains to the athlete what mistakes they made & 0.65 & 0.64 \\
\hline $\begin{array}{l}\text { Provides detailed instruction to the athletes on how to perform specific skills } \\
\text { so as to avoid making mistakes }\end{array}$ & 0.68 & 0.64 \\
\hline Specifies in detail on what skills the athlete needs to learn in a given season & 0.68 & 0.49 \\
\hline Pays special attention to correcting athlete's mistakes & 0.68 & 0.57 \\
\hline
\end{tabular}

\section{Democratic behavior}

Percentage of variance explained

Asks for opinions of the athletes on strategies for specific events or games*

Gets group approval on important matters before going ahead*

8.0

0.64

0.53

0.64

0.63

0.49

0.67

0.37

0.65
5.5

0.78

0.61

0.65

0.55

0.38

0.52

0.57

0.35

Lets athletes actively participate in preparing training plans

\section{Autocratic behavior}

Percentage of variance explained

Does not take into consideration the suggestions of the athletes when planning

the training schedule

Does not explain his/her decisions to the athletes

Does not allow the athletes to make their own decisions

Makes all decisions without consulting the athletes first

Does not explain his/her goals to the athletes

Emphasizes his/her authority and position in the team

\section{Social support}

Percentage of variance explained

Does personal favors for the athletes*

Encourages close and informal relations between players*

Encourages the athletes to confide in him/her*

Is understanding when the athletes have problems

Initiates informal meetings with the athletes

Helps in solving athletes' personal problems

Always provides good advice
4.1

0.50

5.1

0.49

0.45

0.44

0.54

0.47

0.58

0.29

0.67

0.60

0.64

0.56

0.42

0.31

\section{Positive feedback}

Percentage of variance explained

Appreciates the good work an athlete did and compliments him/her in front of others*

3.5

0.33

0.53

0.66

0.29

0.56

0.53

0.46

5.3

0.61

0.58

0.53

0.65

0.63

0.57

0.52
4.7

0.28

0.50

0.34

0.55

0.68

0.28

0.36

Rewards athletes for good results*

Expresses appreciation when an athlete performs well

Gives credit when credit is due

Praises athletes for good performance during practice

Provides information on the athletes' current skill level

* items originated from the original LSS extracted during the first stage of research 
Table 4. Cronbach's alpha for the final version of the Polish Leadership Scale for Sports

\begin{tabular}{lcc}
\hline Subscale & $\begin{array}{c}\text { Physical } \\
\text { education } \\
\text { students } \\
(n=390)\end{array}$ & $\begin{array}{c}\text { Athletes } \\
(n=90)\end{array}$ \\
\hline Training and instruction & 0.84 & 0.80 \\
Democratic behavior & 0.78 & 0.74 \\
Autocratic behavior & 0.70 & 0.62 \\
Social support & 0.61 & 0.68 \\
Positive feedback & 0.79 & 0.80 \\
\hline
\end{tabular}

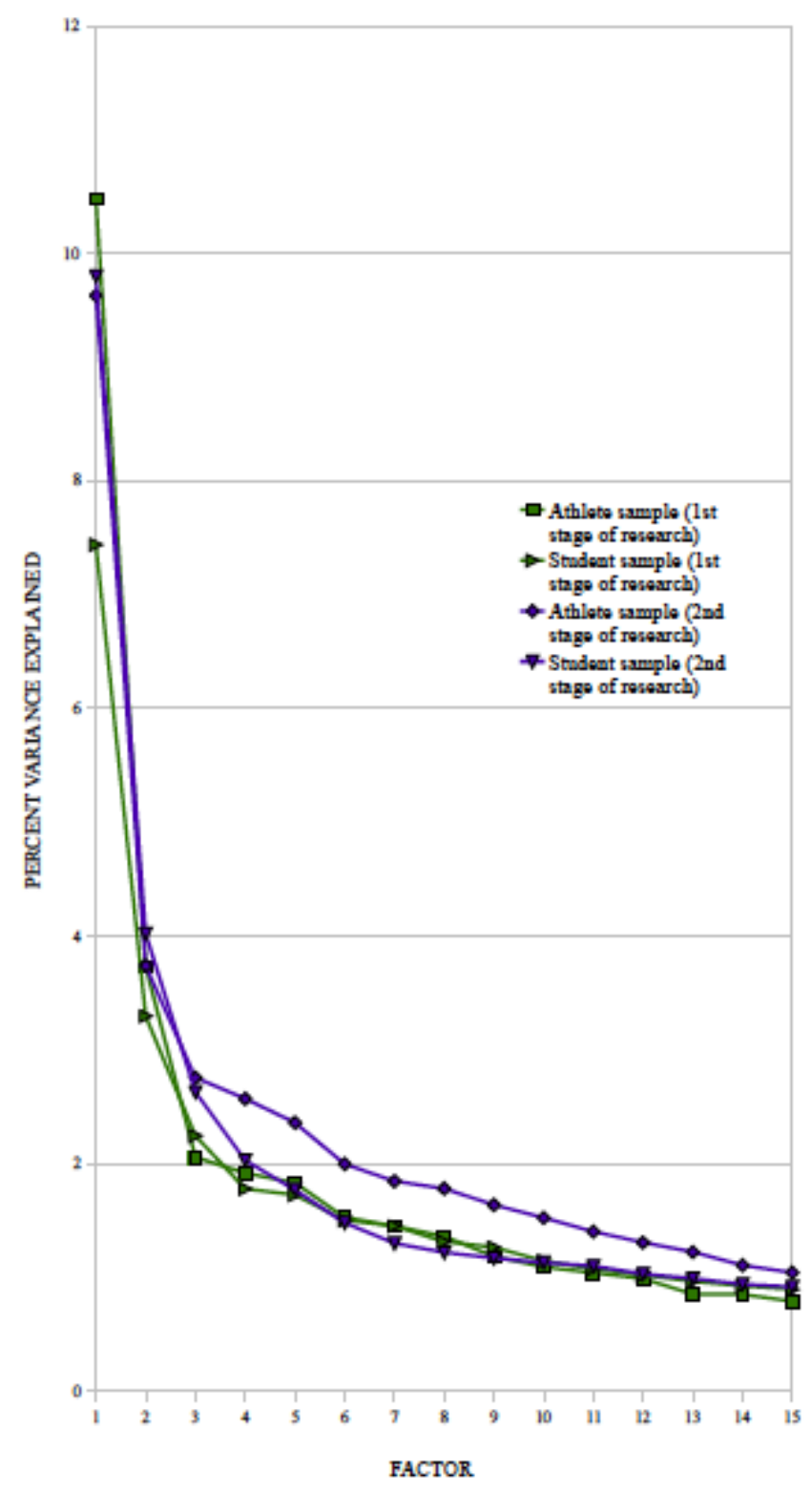

Figure 1. Percent variance explained by successive factors (from the two stages of research on constructing the Polish adaptation of the Leadership Scale for Sports)

\section{Discussion and Conclusions}

The results on the second Polish adaptation of the Leadership Scale for Sports found it to be a reliable and valid tool. Throughout the study, special care was taken to keep the population samples comparable as well as maintain conformity when assessing the reliability and validity the scales or when interpreting the obtained results. This was done so as to maintain the structural, functional, and psychometric equivalence and repeatability of the translated version and the later reconstruction of the original LSS scale [27].

The final questionnaire reflects the original version by also consisting of 40 items measuring five dimensions of coaching behavior: training and instruction - 11 items, democratic behavior -8 items, autocratic behavior -7 items, social support - 7 items, and positive feedback -7 items (see Appendix). However, the Polish adaptation of the LSS is not an exact reproduction of the original English version. Changes in the structure of the scale were introduced so as to improve the psychometric properties of the tool for a Polish population. The Polish adaptation differs from the original LSS primarily in the wording of certain items and the number of items constructing each subscale (the number of items for each dimension were: training and instruction - 13 items, democratic behavior -9 items, autocratic behavior -5 items, social support -8 items, and positive social support - 5 items [10]). The autocratic behavior and social support subscales were expanded due to first adaptation's psychometric weakness. The final adaptation of the Polish LSS included only 22 items that were a direct translation of the original. The remaining items were rewritten so as to be in accordance with Chelladurai's initial leadership theory [6] and follow the later improvements he introduced to improve the Leadership Scale for Sports [12]. In this study's adaptation of the scale, coaches and athletes were recruited to aid in the process of creating these new items, with the content (wording) judged for validity by a group of competent experts.

The reliability of this adaptation is comparable with the Cronbach's alpha values obtained by Chelladurai and Saleh [10]. Lower reliability was found only in the subscale measuring social support. Therefore, future researchers should be cautious when interpreting their results for this dimension. Surprisingly, the subscale measuring autocratic behavior was almost entirely reconstructed based on the original LSS $[6,10,12]$. Cronbach's alpha for this subscale in the Polish adaptation was at satisfactory levels, whereas the Revised Leadership Scale for Sports had numerous objections and problems with obtaining acceptable reliability for this dimension $[12,20]$.

In-depth psychometric analysis permitted to reconstruct the five-factor structure of the original questionnaire. Additionally, confirmatory factor analysis confirmed the validity of this five-factor model of coaching behavior. 
Analysis on factor loading and the content of each item associated with each factor found that both the original structure and names of the various dimensions of coaching behavior could be maintained without modification.

This analysis was performed on both versions of the scale: athletes' preferences for coaching behavior and athletes' perception of their coach's actual behavior. The self-reported version for coaches' perception of their behavior was also included in the study, however, the $\mathrm{KMO}$ measure of sampling adequacy obtained for this version of the scale was insufficient to allow further statistical analysis. This is not entirely surprising, as when constructing the original Leadership Scale for Sports, the psychometric properties of this version for coaches was not examined. Nevertheless, it is still included in the questionnaire as one possible measurement variant that could be used $[10,12]$. Therefore it is recommended that this adaptation of the Leadership Scale for Sports be used only in surveying the opinions or preferences of athletes on coaching behavior without using the selfreport version for coaches (the two versions for athletes are provided in the Appendix).

The presented Polish adaptation of the Leadership Scale for Sports is the latest and, so far, the only reliable and valid tool available in Poland that can be used to study coaching behavior and wider issues connected with leadership in sports. This tool can diagnose coaching style and its interaction with athletes as well as determine the extent to which a coach provides feedback and positive social support to his/her players. Various studies have shown that coaches perceived by their athletes to frequently engage in democratic behavior and provide training and instruction and positive feedback, while rarely being autocratically-minded, have more cohesive teams $[13,17,28-30]$. It has been shown that the behavior of a coach can also significantly affect the internal motivation of athletes and thus indirectly influence their endurance levels [31].

It is hoped that the presented Polish adaptation of the Leadership Scale for Sports can be used to assess the discrepancies that may currently exist between Polish athletes' expectations and the actual coaching behavior they experience. The Multidimensional Model of Sport Leadership theorizes that athlete satisfaction and performance is the result of the interaction between athletes' or a group's required, currently presented, and preferred coaching behavior $[5,6,9]$. Numerous studies have confirmed the link between athlete satisfaction and performance as the result of a divergence between athletes' expectations of coaching behavior and the actual presented behavior. The larger the discrepancy in terms of training and instruction, social support, and positive feedback, the lower the satisfaction athletes have and, as a result, worse performance $[11,13,15]$. The behavior of a coach, particularly the compatibility between a coach's behavior and the expectations of his/her athletes, are known to also have a significant impact on the development of a collective efficacy, which has also been found to be an important factor on performance in team sports [29].

The previously mentioned studies all emphasize the importance of being aware of the differences that may exist between the preferences of athletes and the actual behavior of their coach. This study's adaptation of the Leadership Scale for Sports is the first Polish version of this tool that can effectively investigate this issue. It is hoped future studies will take advantage of this tool to further determine the significance of any differences in the expectations of Polish athletes and the type of coaching behavior they experience and its impact on, among other aspects, athlete satisfaction, effectiveness, and team cohesion. Such studies will also be able to determine the validity - especially predictive validity - of this adaptation of the Leadership Scale for Sports.

\section{References}

1. Czajkowski Z., Psychology as an ally of the coach [in Polish]. COS, RCMSKFiS, Warszawa 1996.

2. Herzig M., Psychological modalities and skills and the efficiency of the coach's work [in Polish]. Sport Wyczynowy, 2002, 5-6, 23-31.

3. Herzig M., Coach - athlete - psychologist [in Polish]. Sport Wyczynowy, 2004, 7-8, 13-19.

4. Czajkowski Z., Leadership theories and their importance in sports [in Polish]. Sport Wyczynowy, 2003, 3-4, 77-89.

5. Chelladurai P., Carron A.V., Leadership. CAHPER Sociology of Sport Monograph Series. University of Calgary, Calgary 1978.

6. Chelladurai P., A contingency model of leadership in athletics. Unpublished doctoral dissertation, University of Waterloo, Ontario 1978.

7. Krawczyński M., Group tactical decisions in team sport games: the perspective of the influences paradigm (on the example of football) [in Polish]. AWF, Gdańsk 1999.

8. Weiss M.R., Friedrichs W.D., The influence of leader behaviors, coach attributes and institutional variables on performance and satisfaction of college basketball teams. J Sport Psychol, 1986, 8 (4), 332-336.

9. Chelladurai P., Leadership in sports. In: Tenenbaum G., Eklund R.C. (eds.), Handbook of sport psychology ( $3^{\text {rd }}$ ed.). John Wiley \& Sons, Hoboken, New Jersey 2007, 113-135.

10. Chelladurai P., Saleh S.D., Dimensions of leader behavior in sports: Development of a leadership scale. J Sport Psychol, 1980, 2 (1), 34-45.

11. Chelladurai P., Discrepancy between preferences and perceptions of leadership behavior and satisfaction of athletes in varying sports. J Sport Psychol, 1984, 6, 27-41.

12. Chelladurai P., Models and measurement of leadership in sport. In: Tenenbaum G., Eklund R.C., Kamata A. (eds.), Measurement in sport and exercise psychology. Human Kinetics, Champaign 2012, 433-442.

13. Weinberg R.S., Gould D., Foundations of sport and exercise psychology. Human Kinetics, Champaign 2007.

14. Horn T.S., Bloom P., Berglund K.M., Packard S., Relationship between collegiate athletes' psychological characterictics and their preferences for different types of coaching behavior. Sport Psychol, 2011, 25 (2), 190-211. 
15. Bahrami S., Zardoshtian S., Jourkesh M., The effect of leadership on the motivation and satisfaction of Iranian women premier basketball league. Ann Biol Res, 2011, 2 (4), 321-329.

16. Loughead T.M., Hardy J., An examination of coach and peer leader behaviors in sport. Psychol Sport Exerc, 2005, 6 (3), 303-312, doi: 10.1016/j.psychsport.2004.02.001.

17. Shields D.L.L., Gardner D.E., Bredemeier B.J.L., Bostro A., The relationship between leadership behaviors and group cohesion in team sports. J Psychol, 1997, 131 (2), 196-210, doi: 10.1080/00223989709601964.

18. Sherman C.A., Fuller R., Speed H.D., Gender comparisons of preferred coaching behaviors in Australian sports. J Sport Behav, 2000, 23 (4), 389-406.

19. Terry P.C., The coaching preferences of elite athletes competing at Universiade 83. Can J Appl Sport Sci, 1984, 9, 201-208.

20. Zhang J., Jensen B.E., Mann B.L., Modification and revision of Leadership Scale for Sports. J Sport Behav, 1997, 20 (1), 105-121.

21. Szulawski M., Tokarski S., The Revised Leadership Scale for Sport [in Polish]. Studia Psychologica, 2007, 7, 385-402.

22. Chelladurai P., Riemer H., Measurement of leadership in sports. In: Duda J.L. (ed.), Advances in sport and exercise psychology measurement. Fitness Information Technology, Morgantown 1998, 227-253.

23. Hornowska E., Paluchowski W., Cultural adaptation of psychological tests [in Polish]. In: Brzeziński J. (ed.), Methodology of psychological research [in Polish]. PWN, Warszawa 2004, 151-191.

24. Brzozowski P., The scale of positive and negative feelings SUPIN. Polish adaptation of the PANAS David Watson and Lee Ann Clark. Handbook [in Polish]. Pracownia Testów Psychologicznych Polskiego Towarzystwa Psychologicznego, Warszawa 2010.
25. Williams L.J., Holahan P.J., Parsimony-based fit indices for multiple-indicator models: do they work? Struct Equation Model, 1994, 1(2), 161-189, doi:10.1080/10705 519409539970.

26. Amorose A.J., Horn T.S., Intrinsic motivation: relationship with collegiate athletes' gender, scholarship status, and perceptions of their coaches' behavior. J Sport Exerc Psychol, 2000, 22 (1), 63-84.

27. Drwal R.Ł., Adaptation of personality questionnaires [in Polish]. PWN, Warszawa 1995.

28. Westre K.R., Weiss M.R., The relationship between perceived coaching behaviors and group cohesion in high school football teams. Sport Psychol, 1991, 5 (1), 41-54.

29. Carron A.V., Hausenblas H.A., Eys M.A., Group dynamics in sport $\left(3^{\text {rd }}\right.$ ed). Fitness Information Technology, Morgantown 2005.

30. Vincer D.J.E., Loughead T.M., The relationship among athlete leadership behaviors and cohesion in team sports. Sport Psychol, 2010, 24 (4), 448-467.

31. Vallerand R.J., Losier G.F., An integrative analysis of intrinsic and extrinsic motivation in sport. J Appl Sport Psychol, 1999, 11 (1), 142-169, doi: 10.1080/104132099 08402956.

Paper received by the Editors: March 4, 2013

Paper accepted for publication: July 11, 2013

Correspondence address

Zuzanna Wałach-Biśta

Katedra Psychologii Społecznej i Środowiskowej

Uniwersytet Śląski

ul. M. Grażyńskiego 53

40-126 Katowice, Poland

e-mail: zuzanna.walach@us.edu.pl

\section{Appendix: The Polish version of the Leadership Scale for Sports}

\section{SKALA PRZYWÓDZTWA W SPORCIE (Preferencje sportowców)}

Każde z poniższych stwierdzeń opisuje konkretne zachowania, które trener może przejawiać. Dla każdego stwierdzenia jest pięć możliwości:
1. NIGDY
2. RZADKO (około $25 \%$ czasu)
3. OKAZYJNIE $(50 \%$ czasu)
4. CZESTO (około $75 \%$ czasu)
5. ZAWSZE

Proszę, zaznacz swoje preferencje dotyczące zachowania trenera poprzez umieszczenie “X” w odpowiednim polu. Odpowiedz na wszystkie stwierdzenia, nawet jeśli nie jesteś któregoś pewny. Pamiętaj, że nie jest to ocena Twojego trenera, z którym współpracujesz - mają to być Twoje osobiste preferencje dotyczące zachowania trenera. Nie ma tutaj dobrych ani złych odpowiedzi.

1. każdemu zawodnikowi wyjaśniał techniki i taktyki konkretnej dyscypliny.

2. pytał o opinię zawodników na temat wyboru strategii na konkretne zawody czy mecz.

3. wyświadczał zawodnikom osobiste przysługi.

4. doceniał zawodników za dobre wyniki i wyrażał swoje uznanie w towarzystwie innych osób.

5. odmawiał pójścia na kompromis.

6. przewidywał, co powinno zostać zrobione.

7. uzyskiwał zgodę grupy co do ważniejszych kwestii zanim sam rozpocznie ich realizację. 
8. zachęcał do bliskich i nieformalnych relacji między zawodnikami.

$----8$

9. mówił zawodnikom, jeżeli wykonają zadanie szczególnie dobrze.

$----9$

10. od każdego zawodnika oczekiwał realizacji swojego zadania w najmniejszym szczególe.

$----10$

11. zachęcał zawodników, aby wysuwali własne propozycje prowadzanie treningów.

$----11$

12. zachęcał, by zawodnicy zwierzali się mu.

13. nagradzał zawodników za dobre wyniki.

14. pozwalał zawodnikom na udział w podejmowaniu decyzji.

$----12$

15. pozwalał zawodnikom na sprawdzenie ich własnych sposobów i pomysłów, nawet jeżeli popełniają błędy. _ _ - - - - 15

16. wyrażał uznanie, jeżeli zawodnicy dobrze się spiszą.

17. nie brał pod uwagę w trakcie planowania treningów sugestii zawodników.

18. rozumiał, że na wysiłek zawodników składa się wiele elementów.

19. pytał zawodników o zdanie na temat ważnych kwestii trenerskich.

20. wyrażał uznanie, jeżeli się ono należy.

21. nie tłumaczył swoich decyzji zawodnikom.

22. wyjaśniał każdemu zawodnikowi, co powinno oraz co nie powinno być robione.

23. chwalił zawodników za dobrze wykonane ćwiczenia na treningach.

24. określał szczegółowo, jakie są oczekiwania względem zawodników.

25. liczył się ze zdaniem i opinią zawodników.

26. okazywał zrozumienie, kiedy zawodnicy mają problemy.

27. nie pozwalał zawodnikom na podejmowanie samodzielnych decyzji.

28. instruował każdego zawodnika indywidualnie w zakresie niezbędnych dla niego umiejętności w konkretnej dyscyplinie sportowej.

29. inicjował nieformalne spotkania towarzyskie z zawodnikami.

30. sam podejmował wszystkie decyzje i nie konsultował ich z zawodnikami.

31. wskazywał zawodnikom dokładnie, jakie błędy popełnili.

32. pozwalał, aby zawodnicy aktywnie uczestniczyli w przygotowaniu planów szkoleniowych.

33. nie tłumaczył wyznaczanych przez niego celów względem zawodników.

34. szczegółowo instruował zawodników, jak wykonywać poszczególne ruchy, by unikać popełnianych błędów.

35. pomagał w rozwiązywaniu osobistych problemów zawodników.

36. dostarczał informacji zawodnikom na temat poziomu ich aktualnych umiejętności.

37. zawsze służył dobrą radą.

38. podkreślał swoją władzę i pozycję w drużynie.

39. dostarczał zawodnikom szczegółowych informacji na temat umiejętności, których muszą się w danym sezonie nauczyć.

40. zwracał szczególną uwagę na korygowanie błędów popełnianych przez zawodników.

- - - - 16

$----17$

$----18$

$----19$

$----20$

$----21$

$----22$

$----23$

$----24$

$----25$

$----26$

$----27$

$----28$

$----29$

- - - 30

- - - - 31

$----32$

$----33$

- - - - 34

- - - - 35

$----36$

- - - - 37

$----38$

$----39$

- - - - 40

\section{SKALA PRZYWÓDZTWA W SPORCIE}

(Zachowanie trenera postrzegane przez sportowców)

Każde z poniższych stwierdzeń opisuje konkretne zachowania, które trener może przejawiać. Dla każdego stwierdzenia jest pięć możliwości:

1. NIGDY

2. RZADKO (około $25 \%$ czasu)

3. OKAZYJNIE (50\% czasu)

4. CZESTO (około $75 \%$ czasu)

5. ZAWSZE

Proszę, zaznacz, jak zachowuje się Twój trener poprzez umieszczenie "X" w odpowiednim polu. Odpowiedź na wszystkie stwierdzenia, nawet jeśli nie jesteś pewny któregoś. Pamiętaj, że oceniasz zachowanie Twojego aktualnego trenera. Nie ma tutaj dobrych ani złych odpowiedzi. Twoja spontaniczność i szczerość udzielanych odpowiedzi jest ważna dla powodzenia tych badań.

Mój trener:

1. każdemu zawodnikowi wyjaśnia techniki i taktyki konkretnej dyscypliny.

$----1$

2. pyta o opinię zawodników na temat wyboru strategii na konkretne zawody czy mecz.

$----2$

3. wyświadcza zawodnikom osobiste przysługi.

4. docenia zawodników za dobre wyniki i wyrażał swoje uznanie w towarzystwie innych osób.

$----3$

5. odmawia pójścia na kompromis.

6. przewiduje, co powinno zostać zrobione.

7. uzyskuje zgodę grupy co do ważniejszych kwestii zanim sam rozpocznie ich realizację.

$----4$

$----5$

8. zachęca do bliskich i nieformalnych relacji między zawodnikami.

$----6$

$----7$

$----8$ 


\section{HUMAN MOVEMENT}

Z. Wałach-Biśta, Polish adaptation of Leadership Scale for Sports

9. mówi zawodnikom, jeżeli wykonają zadanie szczególnie dobrze.

10. od każdego zawodnika oczekuje realizacji swojego zadania w najmniejszym szczególe.

$----9$

11. zachęca zawodników, aby wysuwali własne propozycje prowadzanie treningów.

$----10$

12. zachęca, by zawodnicy zwierzali się mu.

13. nagradza zawodników za dobre wyniki.

14. pozwala zawodnikom na udział w podejmowaniu decyzji.

$----11$

$----12$

$----13$

15. pozwala zawodnikom na sprawdzenie ich własnych sposobów i pomysłów, nawet jeżeli popełniają błędy.

16. wyraża uznanie, jeżeli zawodnicy dobrze się spiszą.

17. nie bierze pod uwagę w trakcie planowania treningów, sugestii zawodników.

- - - - 14

18. rozumie, że na wysiłek zawodników składa się wiele elementów.

19. pyta zawodników o zdanie na temat ważnych kwestii trenerskich.

20. wyraża uznanie, jeżeli się ono należy.

21. nie tłumaczy swoich decyzji zawodnikom.

22. wyjaśnia każdemu zawodnikowi, co powinno oraz co nie powinno być robione.

23. chwali zawodników za dobrze wykonane ćwiczenia na treningach.

24. określa szczegółowo, jakie są oczekiwania względem zawodników.

25. liczy się ze zdaniem i opinią zawodników.

26. okazuje zrozumienie, kiedy zawodnicy mają problemy.

27. nie pozwala zawodnikom na podejmowanie samodzielnych decyzji.

28. instruuje każdego zawodnika indywidualnie w zakresie niezbędnych dla niego umiejętności w konkretnej dyscyplinie sportowej.

29. inicjuje nieformalne spotkania towarzyskie z zawodnikami.

30. sam podejmuje wszystkie decyzje i nie konsultuje ich z zawodnikami.

31. wskazuje zawodnikom dokładnie, jakie błędy popełnili.

32. pozwala, aby zawodnicy aktywnie uczestniczyli w przygotowaniu planów szkoleniowych.

33. nie tłumaczy wyznaczanych przez niego celów względem zawodników.

34. szczegółowo instruuje zawodników, jak wykonywać poszczególne ruchy, by unikać popełnianych błędów.

35. pomaga w rozwiązywaniu osobistych problemów zawodników.

36. dostarcza informacji zawodnikom na temat poziomu ich aktualnych umiejętności.

37. zawsze służy dobrą radą.

38. podkreśla swoją władzę i pozycję w drużynie.

39. dostarcza zawodnikom szczegółowych informacji na temat umiejętności, których muszą się w danym sezonie nauczyć.

40. zwraca szczególną uwagę na korygowanie błędów popełnianych przez zawodników.

$----15$

$----16$

$----17$

$----18$

$---19$

- - - - 20

- - - - 21

- - - - 22

$----23$

- - - - 24

$----25$

- - - - 26

- - - - 27

$----28$

$----29$

- - - - 30

- - - - 31

- - - - 32

- - - - 33

- - - - 34

- - - - 35

- - - - 36

$----37$

- - - - 38

- - - - 39

- - - - 40 